\title{
Coordination among Ministries/Institution in the Context of Reducing Poverty
}

\author{
Elvianus Arya Indra Kusuma ${ }^{1}$, Roy Valiant Salomo ${ }^{2}$ \\ elvianusindra@gmail.com,royvsalomo2357@gmail.com²

\begin{abstract}
Administration Studies Program, Faculty of Administrative Sciences, Universitas Indonesia, Depok, 16424, Indonesia ${ }^{1}$, Administration Studies Program, Faculty of Administrative Sciences, Universitas Indonesia, Depok, 16424 Indonesia $^{2}$
\end{abstract}

\begin{abstract}
Statistics Indonesia's report 2005-2017 shows Indonesia has succeeded in reducing poverty. However, the decline of poverty level rate was not comparable with the budget increase allocated for the poverty reduction program. The massive budget allocated for the program and the group of ministries/institutions executing the program were expected to resolve the poverty problems shortly. However, the rate of poverty reduction has become at stagnante state, with a near-zero decline per year since 2012. This study aims to analyze coordination among ministries/institutions in the context of reducing poverty in Indonesia from the perspective of the Whole-of-Government and factors affecting coordination among ministries/institutions in the context of poverty reduction in Indonesia. This study applied the post-positivism method as an approach to analyzing the problem and utilized the data from the survey. This study concluded that a Whole-ofGovernment approach is needed as a solution to the problem of coordination among existing stakeholders.
\end{abstract}

Keywords: coordination; whole; government; poverty; reduction

\section{Introduction}

Improving prosperity for all Indonesian people is one of the ideals of a state for the Indonesian people as listed in the opening of the 1945 Constitution. For a long time, the government focused on high economic growth to support the priorities to reduce poverty and to maintain economic growth in Indonesia. This effort affected the economy and ensured a process of structural change in the economic field. Besides, the government also concentrated in the fields of health, education, and the economy [1].

Statistics Indonesia data from 2005 to 2018 showed that Indonesia succeeded in reducing poverty, but there was an increase of the sparse population by 1.78 percent, from 15.97 percent in 2005 to 17.75 percent in 2006 [2]. Then in 2015, there was an increase to 0.17 percent, from 10.96 percent in 2014 to 11.13 percent in 2015 . The increase was due to a high increase in prices of basic necessities as a result of rising fuel prices during that period, which resulted in people classified as not inferior but have incomes around the poverty line shifted to the poor [3].

Meanwhile, to support poverty reduction, budget allocation support is needed. The poverty reduction budget from 2005 to 2017 always increased. In 2017, the allocation for the poverty 
reduction program was IDR228.2 trillion. Since 2005, the allocation has been increased to IDR200.2 trillion.

In its implementation, in each period of his administration, the president establishes ministries/institutions as the team in poverty reduction as illustrated in table 1.1 below.

Table 1.1 Poverty Reduction Team

\begin{tabular}{|c|c|c|}
\hline Years & Presidential Decree & Number of Ministries/Institutions \\
\hline $2005-2009$ & No. 54 in 2005 & 25 Ministries/Institutions \\
\hline $2009-2010$ & No. 13 in 2009 & 29 Ministries/Institutions \\
\hline $2010-2015$ & No. 15 in 2010 & 17 Ministries/Institutions \\
\hline $2015-$ new & No. 96 in 2015 & 22 Ministries/Institutions \\
\hline
\end{tabular}

Source: [4], [5], [6], [7].

In addition to involving ministries/institutions, this team also included elements of the community and the private sector. The poverty reduction program carried out by the ministry/institution then implements the program planning process so it could be applied in the activities of each ministry/institution. Planning in this study was interpreted as a means used to obtain goals in the form of realizing predetermined and well-formulated to achieve social, political, or military goals [8].

The results of this study reinforce the results of previous studies on the weaknesses of government programs in poverty reduction programs, namely the lack of coordination between parties in the program implementation that hinders/derails the poverty reduction programs in Indonesia from running independently.

The average percentage of poverty from 2005 to 2017 as one of the government's priority programs continued to decline, while the HDI during the same year increased, but the budget allocation for poverty reduction programs increased in each year as see in in Figure 1.1 below:

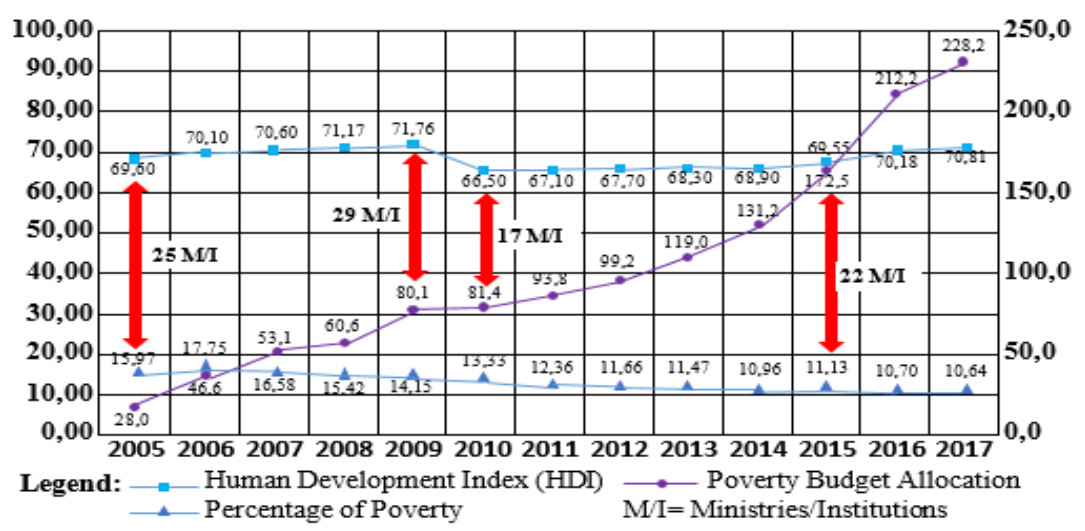

Figure 1.1. Percentage of Poverty, HDI, Poverty Budget Allocation for 2005 - 2017 Source: processed by researchers 
Increasing budget allocations carried out by multiple ministries/institutions so that coordination between ministries/institutions is needed to reduce poverty. Thus raising the formulation of research questions in the form of:

1. What is the level of collaboration between ministries/institutions in planning and budgeting in the context of reducing poverty in Indonesia from the Whole-of-Government perspective? 2. What factors influence cooperation between ministries/institutions?

\section{Method}

The study entitled "Coordination between Ministries/Institutions in the Context of Reducing Poverty" was qualitative research applying post-positivism approach, using descriptive research, in which observation and survey were conducted to collect primary and secondary data, field studies were conducted through interviews, and document studies for obtaining data and information. Data collection techniques used were in-depth interviews with resource persons directly related to ministries/institutions related to poverty reduction programs and document studies, such as news or information related to the Whole-of-Government and poverty reduction programs at ministries/institutions including on the websites, newspapers, magazines, and books.

Then, the data and information obtained related to cooperation between ministries/institutions were examined according to the level of technology used in the collaboration, in order to be classified if the collaboration performed is the lowest level of cooperation value, that is through correspondence between the collaborating ministries/institutions or had been up to the highest level of collaboration, which used a database of inter-ministry/collaborating institutions as described in Deloitte Research [9].

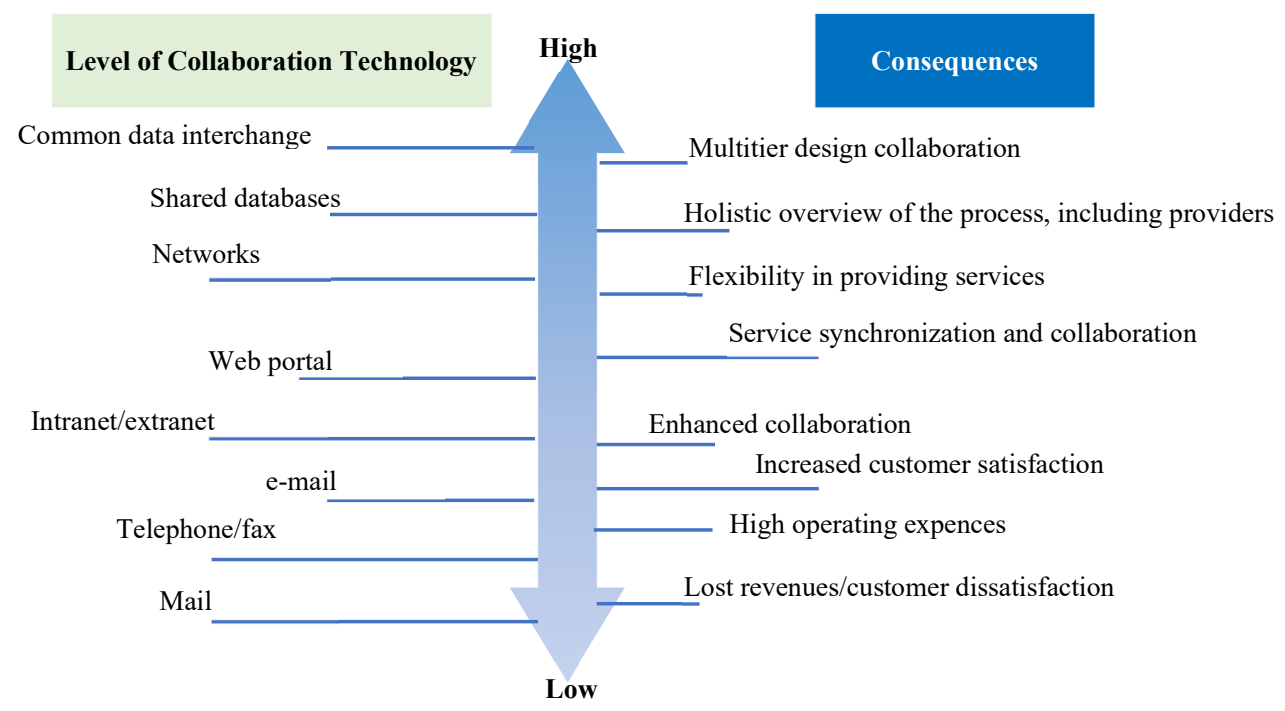

Figure 2.1. Collaboration Technology and Organization Performance Source: Deloitte Research [9] 
The research used the same method to obtain data regarding the factors that influenced the coordination between ministries/institutions. The data obtained were then classified according to the indicators, namely specialization, strength, performance management (performance management), territorial (turf), beliefs and ideology, politics, politics, and accountability [10] [11].

In observing data as a continuation of the process of data that had been collected, the research used the Whole-of-Government method (which is interpreted as a method that analyzes the coordination and management of series of activities between organizational units that do not have hierarchical control or each other and where the aim is to produce results which cannot be achieved by a self-working unit) to eliminate parts (silos) or ministries/institutions that worked independently and hoped to achieve the objectives of the government. The Whole-ofGovernment method aims to optimize the achievement of government objectives by using all state-owned ministries/institutions in an integrated manner to support the achievement of specific government programs.

In implementing poverty reduction programs, there were a lot of Ministries/Institutions involved. This research focused on poverty reduction programs carried out at the National Planning and Development Agency/Ministry of Planning and National Development (Planning), Ministry of Finance (Allocation), Ministry of Social Affairs, Ministry of Basic and Secondary Education (formerly known as Ministry of Education and Culture), and Ministry of Health. While the programs implemented are Family Hope Program (PKH) and Rice Assistance (Rastra) were considered as a manifestation of welfare factors [12], National Health Insurance for Assistance Recipients (JKN-PBI) was considered as manifestations of health factors [12], and "Smart Indonesia" Program (PIP) was considered as an expression of educational factors [12].

\section{Result and Discussion}

\section{Level of Collaboration between Ministries/ Institutions in Planning and Budgeting in the Context of Reducing Poverty Rate in Indonesia in the Whole of Government Perspective}

To measure the level of cooperation between units in government, Goldsmith and William (2004) used Deloitte Research to see from the technology used, from traditional to modern.

\subsection{Mail}

Hierarchy is a common source of strength for the type of organizational culture that was formed from a bureaucratic system that influenced through rules and procedures, reliable power, and very formal communication. The interviews concluded that the coordination carried out using letters related to poverty reduction programs between units at one ministry/institution or between ministries/institutions was a form of compliance with Standard Operating Procedures (SOPs) or applicable regulations. Relationships are formal, and communication is not excellent both inside and outside the organization. Goldsmith and Wiliam [9] added that according to Deloitte Research, coordination conducted by using letters results in loss of income or consumer dissatisfaction. 


\subsection{Telephone/Fax}

The interviews related to the use of technology in the form of telephone and fax related to the implementation of poverty reduction coordination showed that the use of telecommunications equipment in the form of telephone or facsimile, was an unofficial means so that it is only used to communicate to exchange information. Therefore, according to Goldsmith and William [9], the success of a network requires strong digital support, although the network can still be operated by fax, telephone, and meetings, without a deep electronic link to each network partner, government network management is likely to fail. The use of telephone and fax is consistent with Deloitte Research, who stated that the use of this technology has consequences in the form of high operational costs.

\subsection{E-mail}

The use of e-mail as a means of information and up-to-date technology has been used as means of communication between ministries/institutions that implement poverty reduction programs. However, in meeting the follow-up of inter-ministerial/institutional coordination, email was still a simple tool. Bouckaert, Peters, and Verhoest [10] conveyed that coordination requires flexibility and a willingness to think about policy and administration less conventionally, and hence individuals and organizations who are accustomed to operating in stereotypical ways and have been dependent on paths that are usually associated with 'bureaucracy', 'probably will not want to move from the existing pattern'. Unwillingness to move from the existing pattern, of course, contradicted the opinion of Goldsmith and Wiliam [9] who stated that if technology in collaboration has already used email as an administrative level, it means that service user satisfaction has increased.

\subsection{Intranet/extranet}

The next level is the use of intranets or extranets. Every ministry/institution related to the poverty reduction program already has access to the internet or extranet. The intranet and extranet facilities are already connected to each ministry/ institution. However, this facility was not used optimally in order to support the impact of increased collaboration as conveyed by Goldsmith and Wiliam [9] related to the level of Deloitte Research intranet/extranet use.

\subsection{Web Portal}

Each poverty reduction program has used to have a website portal for each poverty reduction program to deliver information of its programs. However, there is no integrated website portal/one portal for all poverty reduction programs. Each poverty reduction program has its website portal. Therefore, ignorance and lack of information can lead to obvious problems. If the information about the functions of other government agencies were not delivered properly, it could hamper joint work. Besides, there was often a strong incentive to maintain confidentiality so that it results in poor coordination, in government [10].

\subsection{Networks}

The next level in the Deloitte Research is the network. In handling poverty reduction in Indonesia, Networks or networks are coordinated by the National Team for the Acceleration of Poverty Reduction (TNP2K). Ministers/institutional leaders are TNP2K members, but there are no units under the ministers/institutional leaders who are members so that coordination runs less optimally which results in the lack of flexibility in providing services [9]. 
This condition is consistent with Firdini's opinion [14] that responds to the need for horizontal coordination forms organizations. Then Bakvis and Juillet [15] add that their formation can range from informal networks between ministries/institutions to formal interministerial/institutional committees, from program-oriented medium-term Task Force Teams to relatively autonomous individual institutions that get resources, and authority.

\subsection{Shared Database}

The results of the interview are following the opinion of Goldsmith and Wiliam [9], who argue that most government databases and information systems are currently inaccessible to vertical parties. This results in employees who work in the ministries/institutions that hold the data often cannot share information with other ministries/institutions, especially with their partners in the private sector and non-profit communities. The combination of vertical and horizontal information barriers within government agencies as well as high walls between ministries/ agencies significantly impedes information sharing. Bouckaert, Peters, and Verhoest [10] add an explanation that there is often a strong desire to maintain confidentiality, thus causing poor coordination in government.

\subsection{Common Data Interchange}

Based on the results of the interview, data sharing has not been running in poverty reduction programs. Each poverty alleviation program has its data so that no data is used together, so there is no collaborative multi-sectoral engagement design. No collaborative multi-sectoral engagement design raises evident problems related to ignorance and lack of information shared about the functions of other government agencies which can hamper joint work. From the above explanation, data sharing has not gone well in the poverty reduction program, so there is no collaborative multi-sectoral engagement design as presented by Goldsmith and Wiliam as an impact of this level according to Deloitte Research [9].

No collaborative multi-sectoral engagement design is in line with data on countries that have implemented e-government that has been published by United Nations, wherein 2018, Indonesia is ranked 107th below Singapore, Malaysia, Brunei Darussalam, Thailand, the Philippines, and Vietnam, as described in Table 3.1 below.

Table 3.1 E-Government Ranking according to The UN E-Government Knowledgebase in 2018

\begin{tabular}{|ccccccc|}
\hline Country Name & $\begin{array}{c}\text { E- } \\
\text { Government } \\
\text { Rank }\end{array}$ & $\begin{array}{c}\text { E- } \\
\text { Government } \\
\text { Index }\end{array}$ & $\begin{array}{c}\text { E- } \\
\text { Participation } \\
\text { Index }\end{array}$ & $\begin{array}{c}\text { Online } \\
\text { Service } \\
\text { Index }\end{array}$ & $\begin{array}{c}\text { Human } \\
\text { Capital } \\
\text { Index }\end{array}$ & $\begin{array}{c}\text { Tele- } \\
\text { communication } \\
\text { Infrastructure } \\
\text { Index }\end{array}$ \\
\hline Singapore & 7 & 0.8812 & 0.9663 & 0.9861 & 0.8557 & 0.8019 \\
\hline Malaysia & 48 & 0.7174 & 0.8876 & 0.8889 & 0.6987 & 0.5647 \\
\hline Brunei Darussalam & 59 & 0.6923 & 0.6067 & 0.7222 & 0.748 & 0.6066 \\
\hline Thailand & 73 & 0.6543 & 0.6517 & 0.6389 & 0.7903 & 0.5338 \\
\hline Philippines & 75 & 0.6512 & 0.9382 & 0.8819 & 0.7171 & 0.3547 \\
\hline Vietnam & 88 & 0.5931 & 0.691 & 0.7361 & 0.6543 & 0.389 \\
\hline Indonesia & 107 & 0.5258 & 0.618 & 0.5694 & 0.6857 & 0.3222 \\
\hline Timor-Leste & 142 & 0.3816 & 0.2697 & 0.3125 & 0.5387 & 0.2937 \\
\hline Cambodia & 145 & 0.3753 & 0.1742 & 0.25 & 0.5626 & 0.3132 \\
\hline Myanmar & 157 & 0.3328 & 0.1348 & 0.2292 & 0.5127 & 0.2565 \\
\hline Source: $[16]$ & & & & & & \\
\hline
\end{tabular}




\section{Factors that Influence Cooperation between Ministries/Institutions}

To find out the factors that influence collaboration between ministries/institutions, this study uses the opinions of Bouckaert, Peters, and Verhoest [10] on the problem of coordination which then specifically by Peters [11] presented variables as below:

\subsection{Specialization}

Based on the results of the interview, the specialization also raises the point of view of each unit or ministry/institution related to the definition of poverty so that it impacts on different service recipient data between poverty reduction programs. There is a concern that coordination could lead to synchronization of poverty alleviation program definitions that have an impact on beneficiaries. The impact of coordination is consistent with the opinion of Bouckaert, Peters, and Verhoest [10], who said that the government is multi-organization. Multi-Organizational nature often influences the quality of public decisions that reflect specialization.

\subsection{Power}

Each ministry/institution in the government has their data/information which comes from their duties. This information or data can become a power for the ministry/institution. However, these data are not shared with other ministries/institutions that have the goal to reduce poverty through coordination data among ministry/institution can achieve the objective of the program [11].

Goldsmith and Wiliam [9], said that currently, most of the government's database and information system are locked to vertical parties so that employees are often unable to share information with other institutions. The combination of information barriers can be vertical and horizontal within government ministries/institutions, and the 'boundary' wall between these ministries/agencies significantly impedes information sharing. They argue that most of the government's database and information systems are currently inaccessible to vertical parties. Bouckaert, Peters, and Verhoest [10] add an explanation that there is often a strong desire to maintain confidentiality, thus causing poor coordination in government.

\subsection{Performance Management}

One element of the New Public Management, performance management, harms coordination. By setting organizational targets, which tend to have an impact on ignoring collective goals [11]. The interview shows that the ministries/institutions get authority from the regulations. The regulations also provide performance targets for the ministry/institution's performance. The performance is following the opinion of Goldsmith and William D. [9] who convey that the measurable performance goals, responsibilities assigned to each partner, and structured information flow with the ultimate goal of this effort is to produce maximum public value, more significant than any player can achieve without collaboration. Fimreite and Lægreid [18] explain by focusing on performance management, single-purpose organizations, and structural devolution, NPM (New Public Management) reforms tend to ignore the problem of horizontal coordination.

\subsection{Territorial (Turf)}

Organizations want to maintain their budgets, personnel, and policies, raising concerns that coordination with other organizations will jeopardize their "territories" [11]. Based on the explanation from the interview, there is control over the work area both in the regions and in the 
center so that they can face the conditions of the data if the regional leader does not want to give or increase the poverty rate of the amount that should be there, the difficulty of sharing data, does not want others to disturb the work area [9].

\subsection{Beliefs and Ideology}

Governmental organizations will become more popular, especially by individuals who have confidence in the mission of their organization. However, researchers did not get information related to this element in the interview.

\subsection{Politics}

In a coalition government, ministries/institutions are controlled by various political parties which can cause coordination problems. Likewise, problems with coordination appear if the regional head is controlled by a political party that is different from the ruling political party at the intermediate level [11]. Information obtained from the interview that the basis for the formation of Ministries/Institutions or poverty reduction programs is the existence of rules in the form of laws or regulations below, this has led to political influence in the implementation of poverty reduction programs.

\subsection{Accountability}

In a government formed by a coalition, the leader of the ministry/institution comes from various political parties. Therefore, it can cause coordination problems among the ministry/institution. Information from interviews obtained that accountability for activities was also carried out responsibly so that coordination was feared would hamper accountability in the implementation of poverty reduction programs. Baechler [20] emphasized that departmental priorities, with a bureaucratic organizational culture, are a framework of accountability, access to resources, and a shift in political interests.

Problems related to coordination are illustrated by the World Bank [21] wherein the implementation of poverty reduction programs, the data used in the implementation of poverty reduction programs have not fully coordinated. The program runs individually with individual data and allocations. So the impact of the implementation of this poverty reduction program is that the reduction program is not on target. As explained in Figure 3.1 below:

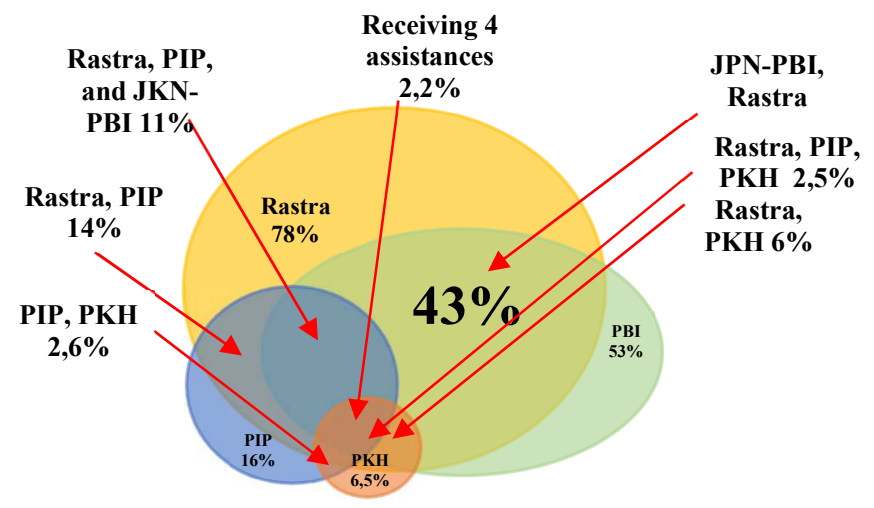

Figure 3.1. Implementation of the Poverty Reduction Program Source: [21] 


\section{Conclusion}

From the research, the conclusion that developed is that the level of collaboration between ministries/institutions in planning and budgeting in the context of poverty reduction in Indonesia from the perspective of the dominant Whole of Government is only in the correspondence stage. Although technological advances have also been implemented in each ministry/institution that implementing poverty reduction programs, data ownership is still a very 'taboo' thing to be widely known. Each program has its data, criteria, and quota, which are run individually by the ministry/ institution that has the authority.

Meanwhile, the factors influencing coordination between ministries/institutions are dominated by ownership of data of each ministry/institution for the programs implemented respectively. Even though they have coordinated with the Integrated Database '(owner)', the data criteria are still determined by ministries/agencies that request data that are adjusted to the program to be run and not synchronized with other actors of poverty reduction programs, resulting in many Poor Households (RTM) as a beneficiary, do not receive all facilities provided by the state. Not receive all facilities provided by the state causes the impact felt by the service recipient to be less pronounced because very few low-income families can receive all the facilities offered by poverty reduction programs implemented by ministries/institutions.

\section{Recommendation}

Poverty reduction should be an output and outcome with ministries/institutions, without having to have their own programs, so that the use of cards that indicate each program has one card can be more streamlined by combining it into one card or even with an electronic Resident Identity Card (e-KTP), so that the poor can be well informed of the services that they deserved.

Optimal use of up-to-date technology which is not only for one ministry/institution but for all ministries/ institutions that run poverty reduction programs that will speed up service delivery which of course will further increase satisfaction with beneficiaries.

Monitoring and evaluation must be held every period, and input obtained from monitoring and evaluation activities should be used as input to improve services to beneficiaries.

\section{References}

[1] Ministry of Finance, Republic of Indonesia, „Buku II: Nota Keuangan Beserta Anggaran Pendapatan dan Belanja Negara Tahun Anggaran 2018, “ Ministry of Finance, Republic of Indonesia, Jakarta, 2018.

[2] S. Indonesia, Statistik Indonesia: Statistical Yearbook of Indonesia 2009, Jakarta: BPS, 2009.

[3] S. Indonesia, „Statistik Indonesia: Statistical Yearbook of Indonesia 2018,“ BPS, Jakarta, 2018. 
[4] G. o. Indonesia, „the Poverty Reduction Coordination Team“. Jakarta Patent 54, 10 September 2005.

[5] G. o. Indonesia, „Poverty Reduction Coordination“. Jakarta Patent 13, 27 March 2009.

[6] G. o. Indonesia, ,the Acceleration of Poverty Reduction“. Jakarta Patent 15, 2010 February 2010.

[7] G. o. Indonesia, ,Amendment to Presidential Regulation Number 15 Years 2010 concerning the Acceleration of Poverty Reduction“. Jakarta Patent 96, 21 August 2015.

[8] M. Jhingan, Ekonomi Pembangunan dan Perencanaan, Jakarta: Rajawali Pers, 2016.

[9] S. a. W. D. E. Goldsmith, Governing by Network: The New Shape of the Public Sector, Washington D.C.: The Brookings Institution, 2004.

[10] G. B. G. P. a. K. V. Bouckaert, The Coordination of Public Sector Organizations: Shifting Patterns of Public Management, Basingstoke: Macmillan, 2010.

[11] B. G. Peters, ,The Challenge of Policy Coordination,“ POLICY DESIGN AND PRACTICE, zv. 1, \%1. vyd.1, p. 1-11, 2018.

[12] C. V. a. N. M. P. Nguyen, „Economic Growth, Inequality, and Poverty in Vietnam,“ ASIAN-PACIFIC ECONOMIC LITERATURE, zv. 32, \%1. vyd.1, pp. 45-58, 2018.

[13] J. M. a. T. J. B. (. Kamensky, Collaboration: Using Networks and Partnerships, United States of America: Rowman \& Littlefield Publishers, Inc., 2004.

[14] P. Dunleavy, The Future of Joined-up Public Services, London: Public Services Trust. London School of Economics, 2010.

[15] H. a. L. J. Bakvis, The Horizontal Challenge : Line Departments, Central Agencies and Leadership, Ottawa: Canada School of Public Service, 2004.

[16] U. Nation, ,publicadministration.un.org,“ United Nation, 2018. [Online]. Available: https://publicadministration.un.org/egovkb/en-us/Data-Center. [Cit. 3 June 2019].

[17] H. A. Simon, „A Comment on "The Science of Public Administration, “ Public Administration Review, zv. 7, \%1. vyd.3, pp. 200-203, 1947.

[18] A. L. a. L. P. Fimreite, ,Specialization and Coordination: Implications for Integration and Autonomy in a Multi-Level System,“ November 2005. [Online]. Available: http://bora.uib.no/bitstream/handle/1956/1336/N0705\%5b1\%5d.pdf?sequence=1\&isAllowed=y. [Cit. 9 September 2016].

[19] P. Fafard, „icpublicpolicy,“ June 2013. [Online]. Available: http://www.icpublicpolicy.org/IMG/pdf/panel_61_s1_fafard_final.pdf. [Cit. 8 March 2018].

[20] H. A. L. J. Bakvis, The Horizontal Challenge : Line Departments, Central Agencies and Leadership, Ottawa: Canada School of Public Service, 2004.

[21] N. T. f. t. A. o. P. R. (TNP2K), Laporan uji coba penyaluran bantuan sosial non-tunai tahun 2016, Jakarta: TNP2K, 2017.

[22] N. \&. F. A. \&. J. B. \&. B. I. Ariyani, „Evaluasi Pogram Pengentasan Kemiskinan Menggunakan Metode Rappoverty," Jurnal Ekonomi dan Kebijakan Publik, zv. 6, \%1. vyd.10, pp. 181-197, 2015.

[23] C. a. S. P. Stefanescu, ,Specific Features of The Organisational Culture of The Local Government,“ Review of General Management, zv. 10, \%1. vyd.2, pp. 89-96, 2009.

[24] B. G. Peters, Managing Horizontal Government: The Politics of Coordination, Ottawa: Canadian Centre for Management Development, 1998. 
[25] Firdini, „Policy Coordination Effectiveness: Analysing Coordination Level in the Formulation of National Development Planning Document in Indonesia, “ rev. Majalah Perencanaqan Pembangunan, Jakarta, Bappenas, 2014, pp. 53-62.

[26] W. Bank, Towards a Comprehensive, Integrated, and Effective Social Assistance System in Indonesia, Jakarta: The World Bank Office, 2017. 